\title{
Long-term survival of robotic lobectomy for non- small cell lung cancer: a literature review
}

\author{
Sara Ricciardi', Federico Davini², Carmelina C. Zirafa², Gaetano Romano², Franca M. A. Melfi \\ 'Division of Thoracic Surgery, Department of Surgical, Medical, Molecular, Pathology and Critical Care, University Hospital of \\ Pisa, Pisa 56124, Italy. \\ ${ }^{2}$ Multispecialty Centre for Surgery, Minimally Invasive and Robotic Thoracic Surgery, University Hospital of Pisa, Pisa 56124, \\ Italy.
}

\begin{abstract}
Correspondence to: Dr. Sara Ricciardi, Division of Thoracic Surgery, Department of Surgical, Medical, Molecular, Pathology and Critical Care, University Hospital of Pisa, Via Paradisa 2, Pisa 56124, Italy. E-mail: ricciardi.sara87@gmail.com
\end{abstract}

How to cite this article: Ricciardi S, Davini F, Zirafa CC, Romano G, Melfi FMA. Long-term survival of robotic lobectomy for non-small cell lung cancer: a literature review. Mini-invasive Surg 2020;4:1. http://dx.doi.org/10.20517/2574-1225.2019.50

Received: 8 Nov 2019 First Decision: 27 Nov 2019 Revised: 9 Dec 2019 Accepted: 20 Dec 2019 Published: 6 Jan 2020

Science Editor: Valérie Lacroix Copy Editor: Jing-Wen Zhang Production Editor: Tian Zhang

\begin{abstract}
Even though robotic-assisted surgery is increasingly used for resection of non-small cell lung cancer (NSCLC), data on long-term oncologic outcomes of robotic surgery are still not well defined. The primary endpoint of this review is to analyse the long-term results of robotic lobectomy in NSCLC patients. A systematic research was performed using the PubMed database. Articles published from January 2008 to January 2019 were included. We excluded studies that did not provide results for the long-term outcomes of robotic lobectomy, studies that had fewer than 50 cases and ones that focused on results of sub-lobar resections. Therefore, ten eligible studies were included in this analysis. In total, 2873 patients, with a mean age ranging between 66 and 68 years, who underwent robotic lobectomy for NSCLC, were analysed. Most patients (81\%) had early-stage disease. The five-year overall survival for stage I disease fluctuated between $77 \%$ and $100 \%$. The five-year disease-free survival was reported to be near $73 \%$. We can conclude that robotic assisted lobectomy is an effective minimally-invasive procedure for lung resection. The current literature shows that robotic lobectomy is associated with long-term survival and lasting disease-free survival, equivalent to those reached by video-assisted thoracic surgery and open approach.
\end{abstract}

Keywords: Non-small cell lung cancer, robotic surgery, robotic lobectomy, long-term outcome, minimally invasive surgery

\section{INTRODUCTION}

Surgical resection of non-small-cell lung cancer (NSCLC) is the preferred local treatment modality for operable disease and lobectomy remains the gold standard treatment in early-stage lung cancer ${ }^{[1]}$. Thanks

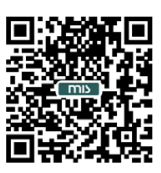


to the technical and technological improvements achieved during the decades, the surgical approach has moved from open procedures to minimally invasive surgery (MIS). MIS [including video-assisted thoracic surgery (VATS) and robot-assisted surgery] has become the preferred approach in patients with no contraindications (anatomic or surgical), given that the less invasive approach does not compromise the oncologic cancer outcomes and is associated with better short-term results compared to thoracotomy ${ }^{[2]}$.

Regardless of the approach, the oncologic principles remain unchanged: the achievement of negative margins (Ro resection) and a systematic lymph node dissection; the open approach for lobectomy remains the cornerstone with which the results of the other techniques are compared.

Recent data have reported an important increase in VATS and robotic lobectomy versus open procedures and several studies have shown that MIS lobectomy results in comparable oncologic outcomes to those of open approach $^{[3,4]}$. However, Level 1 evidence does not exist and data on long-term outcomes for NSCLC patients treated with robotic approach are still lacking ${ }^{[5]}$.

The aim of this review is to analyse the literature concerning the long-term survival of robotic lung lobectomy.

\section{METHODS}

A literature review was conducted by searching PubMed in July 2019, using the search terms: ("lung cancer" OR "lung tumour" OR "lung neoplasm" OR "NSCLC") AND ("robotic" OR "robot assisted" OR "da Vinci" OR “daVinci”) AND [“analysis, survival” (MESH TERMS)].

Inclusion criteria were: (1) the paper described robotic-assisted lobectomy; and (2) the study was a randomised controlled trial, meta-analysis or single centre/multicentre database study recording on robotic lobectomy.

Exclusion criteria were: (1) the study did not provide results for the long-term outcomes of robotic lobectomy; (2) the study focused on results of sub-lobar resections; and (3) the study included fewer than 50 cases.

After language restriction (English), applying inclusion and exclusion criteria and eliminating duplicate papers, ten studies were selected for this analysis, all reporting robotic lung lobectomy for NSCLC [Figure 1].

\section{RESULTS}

Six retrospective, observational single centre studies, three retrospective multicentre studies and one prospective cohort study published between 2008 and January 2019 were included in this analysis [Table 1]. In total, 2873 patients, with a mean age ranging between 66 and 68 years, who underwent robotic lobectomy for NSCLC, were analysed.

The majority of patients (81\%) had early-stage disease [1892 stage I (66\%), 443 stage II (15\%)] and only a few of them had advanced or metastatic disease [507 stage III (18\%), 31 stage IV (1\%)].

\section{Short-term outcomes}

The mean length of stay reported was 4.5 days (ranging between 3 and 8 days), the mean conversion rate was $8.4 \%$ (ranging between $0 \%$ and $9.8 \%$ ) and the mean post-operative 30 -day mortality was $0.25 \%$ (ranging between $0 \%$ and $4.9 \%)$.

The mean rates of reported overall complications and major complications were $25.4 \%$ (ranging between 9.52\% and $66.4 \%$ ) and $5.85 \%$ (ranging between $2.4 \%$ and $10.3 \%$ ), respectively [Table 1 ]. 


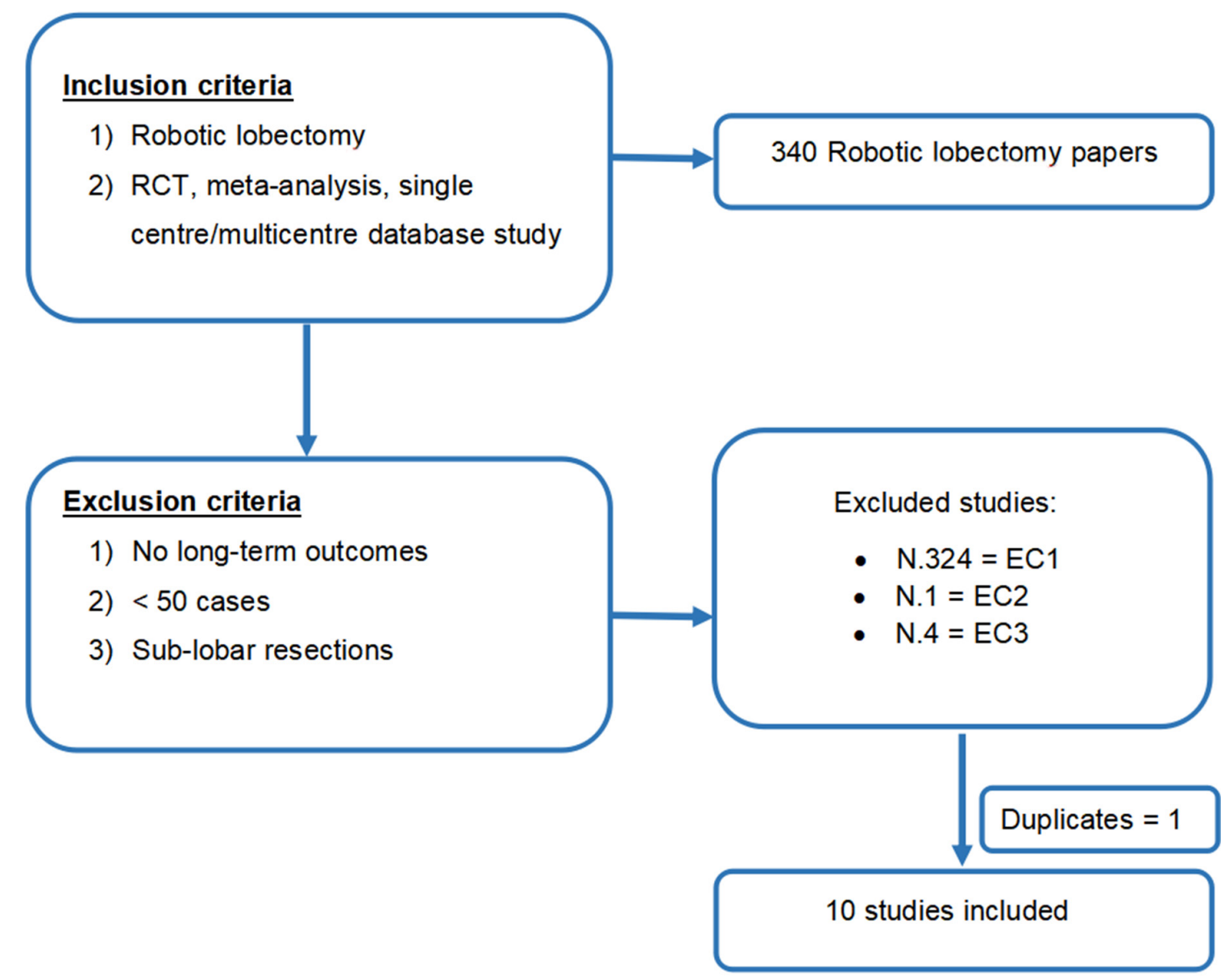

Figure 1. We present graphically our searching strategy. RCT: randomized control trial

\section{Mid- and long-term outcomes}

The mid- and long-term outcomes of 2850 patients were analysed, with a survival time analysis ranging between two years and five years. Seven studies showed the survival of patients who underwent robotic surgery in a single centre with a follow-up ranging between 13.3 and 40.3 months. The studies were inhomogeneous for survival time analysis (two-, three- or five-year results) and patients' stage (only stage I analysis or multiple stage data) [Table 2].

Toosi et al. ${ }^{[6]}$ analysed 249 patients who underwent robotic lobectomy and showed a mean operative-time, conversion rate and rates of perioperative outcomes comparable to those of VATS and open surgery. The primary endpoint of this study was the evaluation of the effectiveness of lymphadenectomy (LN) by robotic approach and the authors revealed that LN staging with robotic surgery was comparable to or better than that obtained with conventional VATS and open approach. Moreover, the authors showed an overall survival (OS) comparable with that described in the literature, but the survival analysis was limited by the short mean follow-up time (18 months).

The aim of the study published by Yang et al. ${ }^{[7]}$ was to compare the long-term outcomes [OS and diseasefree survival (DFS)] of three cohorts (robotic, VATS and open) of clinical stage I NSCLC patients matched by propensity score. The authors stated that MIS lobectomy for clinical stage I NSCLC guarantees comparable long-term survival as thoracotomy and was associated with shorter hospitalisation. The fiveyear OS and DFS for the robotic group were $77.6 \%$ and $72.7 \%$, respectively, and $13.5 \%$ (25/184) patients experimented recurrences. 
Table 1. Short-term outcome of NSCLC treated by Robotic approach

\begin{tabular}{|c|c|c|c|c|c|c|c|c|c|c|}
\hline \multirow{2}{*}{ Ref. } & \multirow{2}{*}{ Year } & \multirow{2}{*}{$\begin{array}{l}\text { Number of } \\
\text { patients }\end{array}$} & \multirow{2}{*}{$\begin{array}{l}\text { Type of } \\
\text { study }\end{array}$} & \multirow{2}{*}{$\begin{array}{l}\text { Conversion } \\
\text { rate }\end{array}$} & \multirow{2}{*}{$\begin{array}{l}n \text { of resected lymph } \\
\text { nodes or } n \text { of station }\end{array}$} & \multirow{2}{*}{ Upstaging } & \multirow{2}{*}{$\begin{array}{l}\text { Hospital } \\
\text { stay (days) }\end{array}$} & \multirow{2}{*}{ Complications } & \multicolumn{2}{|c|}{ Mortality } \\
\hline & & & & & & & & & 30 days & 90 days \\
\hline Toosi et al. ${ }^{[6]}$ & 2016 & 249 & $\begin{array}{l}\text { Retrospective } \\
\text { single centre }\end{array}$ & $22(8.8 \%)$ & $\begin{array}{l}13.9 \pm 0.4 \text { nodes } \\
\text { (range 1-37) }\end{array}$ & $26.9 \%$ & 5 & $90(36.1 \%)$ & $6(2.4 \%)$ & \\
\hline Veronesi et $a l^{[14]}$ & 2018 & 210 & $\begin{array}{l}\text { Retrospective } \\
\text { multicentre }\end{array}$ & $22(9.9 \%)$ & 15.4 nodes (SD 7.9) & NA & 5.3 & $\begin{array}{l}148(66.4 \%) \\
\text { Grade III-IV } 23 \\
(10.3 \%)\end{array}$ & $\begin{array}{l}4 / 209 \\
(1.9 \%)\end{array}$ & $\begin{array}{l}8 / 198 \\
(4 \%)\end{array}$ \\
\hline Yang et al. ${ }^{[7]}$ & 2017 & 172 & $\begin{array}{l}\text { Prospective } \\
\text { single centre }\end{array}$ & $16(9 \%)$ & $\begin{array}{l}5 \text { stations (range } \\
0-8 \text { ) }\end{array}$ & NA & 4 & $51(29.7 \%)$ & 0 & \\
\hline Lee et $a{ }^{[8]}$ & 2015 & 53 & $\begin{array}{l}\text { Retrospective } \\
\text { single centre }\end{array}$ & $1(1.9 \%)$ & $\begin{array}{l}17 \text { nodes (range } \\
4-40 \text { ) }\end{array}$ & $13.2 \%$ & 3 & $6(9.52 \%)$ & 0 & \\
\hline Park et al. ${ }^{[13]}$ & 2011 & 325 & $\begin{array}{l}\text { Retrospective } \\
\text { multicentre }\end{array}$ & $27(8 \%)$ & $\begin{array}{l}5 \text { stations (range } \\
2-8 \text { ) }\end{array}$ & $24 \%$ & 5 & $\begin{array}{l}82(25.2 \%) \\
\text { Major } 12(3.7 \%)\end{array}$ & $1(0.3 \%)$ & \\
\hline Gharagozloo et al. ${ }^{[9]}$ & 2008 & 54 & $\begin{array}{l}\text { Retrospective } \\
\text { single centre }\end{array}$ & 0 & NA & $16 \%$ & 4 & $14(22 \%)$ & $3(4.9 \%)$ & \\
\hline Cheufou et $a l^{[10]}$ & 2019 & 64 & $\begin{array}{l}\text { Retrospective } \\
\text { single centre }\end{array}$ & $6(9.4 \%)$ & 13.9 nodes (SD 6.5) & $12.9 \%$ & $8.3 / 7.9$ & & $0 \%$ & \\
\hline Cerfolio et al. ${ }^{[15]}$ & 2018 & 1321 & $\begin{array}{l}\text { Retrospective } \\
\text { multicentre }\end{array}$ & $116(9 \%)$ & $\begin{array}{l}19 \text { nodes (range 11- } \\
42 \text { ) }\end{array}$ & NA & 3 & $\begin{array}{l}24 \% \\
\text { Major } 8 \%\end{array}$ & $0.2 \%$ & $0.5 \%$ \\
\hline Casiraghi et al. ${ }^{[11]}$ & 2019 & 307 & $\begin{array}{l}\text { Retrospective } \\
\text { single centre }\end{array}$ & $22(6.5 \%)$ & $\begin{array}{l}15 \text { nodes (range } \\
1-55)\end{array}$ & $17.6 \%$ & 5 & $\begin{array}{l}87(25.7 \%) \\
\text { Major } 8(2.4 \%)\end{array}$ & 0 & $0.3 \%$ \\
\hline Zirafa et al. ${ }^{[12]}$ & 2019 & 212 & $\begin{array}{l}\text { Retrospective } \\
\text { single centre }\end{array}$ & $9(4.2 \%)$ & $\begin{array}{l}17.4 \text { nodes (range } \\
7-37 \text { ) }\end{array}$ & NA & 3.6 & $54(25.5 \%)$ & $1(0.4 \%)$ & \\
\hline
\end{tabular}

NSCLC: non-small-cell lung cancer; NA: not assessed

Another comparative study was the one by Lee et $a l .{ }^{[8]}$ The authors retrospectively analysed clinically node negative NSCLC patients who underwent VATS $(n=158)$ or robotic $(n=53)$ lobectomy showing a similar rate of nodal upstaging and similar DFS and OS between the two groups. In the robotic cohort with a mean follow-up of 13.3 months, the OS and DFS were $95 \%$ and $93 \%$, respectively. They reported three (5.6\%) cancer recurrences (all distant). One of the first studies which reported long-term outcomes of robotic surgery was published in 2008 . With a follow-up of 28 months, Gharagozloo et al. ${ }^{[9]}$ reported an OS of $100 \%$ and a DFS of $93 \%$ in a cohort of stage I and II NSCLC patients. No recurrences occurred.

A recent study conducted by Cheufou et al. ${ }^{[10]}$ reported data on 64 patients who underwent robotic lobectomy for lung cancer. Their results showed a two-year survival rate of $83 \%$ with a rate of nodal upstaging of $12.9 \%$.

Analyses of larger groups of patients were performed by Casiraghi et al ${ }^{[11]}$ and Zirafa et al. ${ }^{[12]}$ Casiraghi et al. ${ }^{[1]}$ reported data on 307 lobectomies, 29 segmentectomies and 3 pneumonectomies performed by robotic approach in NSCLC patients (stage IA-IIIA). The five-year OS of the lobectomy cohort was $89.1 \%$ with a DFS of $72.8 \%$. There were 58 recurrences: 16 local (ipsilateral to the operated chest), 27 regional (contralateral) and 15 distant.

Zirafa et al. ${ }^{[12]}$ analysed 212 patients who underwent robotic lobectomy $(n=211)$ and bilobectomy $(n=1)$ for NSCLC (stages IA-IV). With a mean follow-up of 40.3 months, they reported a five-year survival of $98.5 \%$ (stage I), 93.7\% (stage II), 73.1\% (stage III) and 0\% (stage IV). The overall DFS was 66.3 months. Overall, $12.7 \%$ of loco-regional relapse and $10.9 \%$ of distant recurrence were observed.

Three retrospective multicentre studies were also included in this review. The first was conducted by Park and examined data on 325 patients who underwent robotic lobectomies in three high volume centres: 123 patients in New York, 82 in Milan and 120 in Pisa. The majority of the patients (76\%, 248/325) were pathologic stage I (176 stage IA and 72 stage IB). Overall one- and five-year survival for the group was $98 \%$ and $80 \%$, respectively. Twenty-five patients died of their disease. At a mean follow-up of 27 months, the 
Table 2. Mid- and Long-term outcomes of NSCLC treated by Robotic approach

\begin{tabular}{|c|c|c|c|c|c|c|c|c|c|c|c|}
\hline \multirow{3}{*}{$\begin{array}{l}\text { Ref. } \\
\text { Toosi et al. }{ }^{[6]}\end{array}$} & \multirow{3}{*}{$\begin{array}{c}\text { Year } \\
2016\end{array}$} & \multirow{3}{*}{$\begin{array}{l}\begin{array}{l}\text { Number of } \\
\text { patients }\end{array} \\
249\end{array}$} & \multirow{3}{*}{$\begin{array}{l}\begin{array}{c}\text { Type of } \\
\text { study }\end{array} \\
\text { Retrospective } \\
\text { single centre }\end{array}$} & \multirow{3}{*}{$\begin{array}{l}\text { Intervention } \\
\text { Lobectomy }\end{array}$} & \multirow{2}{*}{\multicolumn{2}{|c|}{$\begin{array}{l}\text { Follow-up Survival time } \\
\text { (months) analysis }\end{array}$}} & \multirow{3}{*}{$\begin{array}{l}\text { pStage I } \\
75 \%\end{array}$} & \multirow{2}{*}{\multicolumn{2}{|c|}{$\begin{array}{c}\text { Overall survival } \\
\text { Stage II nStage II }\end{array}$}} & \multirow{2}{*}{ pStage IV } & \multirow{2}{*}{ DFS } \\
\hline & & & & & & & & & & & \\
\hline & & & & & 18 & 3-year & & $73 \%$ & $44 \%$ & $0 \%$ & l \\
\hline Veronesi et al. ${ }^{[14]}$ & 2018 & 210 & $\begin{array}{l}\text { Retrospective } \\
\text { multicentre }\end{array}$ & Lobectomy & 18 & 3-year & I & / & $61.2 \%$ & / & $37.7 \%$ \\
\hline Yang et al. ${ }^{[14]}$ & 2017 & 172 & $\begin{array}{l}\text { Prospective } \\
\text { single centre }\end{array}$ & Lobectomy & 39.8 & 5-year & $77.6 \%$ & / & / & / & $72.7 \%$ \\
\hline Lee et $a l^{[8]}$ & 2015 & 53 & $\begin{array}{l}\text { Retrospective } \\
\text { single centre }\end{array}$ & Lobectomy & 13.3 & 2-year & & $95 \%$ & & / & $93 \%$ \\
\hline Park et al. ${ }^{[13]}$ & 2011 & 325 & $\begin{array}{l}\text { Retrospective } \\
\text { multicentre }\end{array}$ & Lobectomy & 27 & 3-year & $\begin{array}{l}97 \%(I A), \\
88 \%(I B)\end{array}$ & $72 \%$ & $43 \%$ & / & $90 \%$ \\
\hline Gharagozloo et al. ${ }^{[9]}$ & 2008 & 54 & $\begin{array}{l}\text { Retrospective } \\
\text { single centre }\end{array}$ & Lobectomy & 28 & 2-year & $100 \%$ & $100 \%$ & / & / & $93 \%$ \\
\hline Cheufou et al. ${ }^{[10]}$ & 2018 & 64 & $\begin{array}{l}\text { Retrospective } \\
\text { single centre }\end{array}$ & Lobectomy & I & 2-year & & $83 \%$ & & / & I \\
\hline Cerfolio et al. ${ }^{[15]}$ & 2018 & 1321 & $\begin{array}{l}\text { Retrospective } \\
\text { multicentre }\end{array}$ & Lobectomy & 30 & 5-year & $\begin{array}{l}83 \%(I A), \\
77 \%(I B)\end{array}$ & $\begin{array}{l}68 \%(I I A) \\
70 \%(I I B)\end{array}$ & $\begin{array}{l}62 \%(I I I A) \\
31 \%(I I I B)\end{array}$ & $54 \%$ & $\begin{array}{l}\text { Mean DFS: } \\
16 \text { months }\end{array}$ \\
\hline Casiraghi et al. ${ }^{[11]}$ & 2019 & 307 & $\begin{array}{l}\text { Retrospective } \\
\text { single centre }\end{array}$ & Lobectomy & 28.8 & 5-year & & $89.1 \%$ & & / & $72.8 \%$ \\
\hline Zirafa et al. ${ }^{[12]}$ & 2019 & 212 & $\begin{array}{l}\text { Retrospective } \\
\text { single centre }\end{array}$ & $\begin{array}{l}211 \text { Lobectomy } \\
1 \text { Bilobectomy }\end{array}$ & 40.3 & 5-year & $98.5 \%$ & $93.7 \%$ & $73.1 \%$ & $0 \%$ & $\begin{array}{l}\text { Mean DFS: } \\
66.3 \text { months }\end{array}$ \\
\hline
\end{tabular}

DFS: disease free survival; NSCLC: non-small-cell lung cancer

recurrence rate was $10 \%(32 / 325)$. Most recurrences (72\%) were distant (17 distant only; 6 locoregional + distant), and $28 \%(9 / 32)$ were locoregional only ${ }^{[13]}$.

The retrospective multicentre (seven centres) study led by Veronesi et al. ${ }^{[14]}$ analysed 223 patients with NSCLC or carcinoid, with pathological (post-surgical) N2 disease (Stage IIIA) treated by robot assisted resection with curative intent, before or after chemotherapy or chemoradiation therapy. The study included 34 patients who underwent resection after induction therapies. With a mean follow-up of 18 months, mean survival for the 210 NSCLC patients ( 13 carcinoids) was 51 months, with three-year OS estimated at 61.2\%. Twenty-five per cent of patients (56 cases) had distant relapse and $16.6 \%$ had local or lung recurrence.

Cerfolio et al. ${ }^{[15]}$ reported the largest series of robotic lobectomy for NSCLC in four high volume centres. The authors analysed short- and long-term outcomes of 1339 and 1321 patients, respectively. Approximately 50\% of patients had stage IA disease (672/1339). With a mean follow-up of 30 months (ranging between 1 and 154 months), the five-year stage-specific survival was: $83 \%$ for stage IA, $77 \%$ for stage IB, $68 \%$ for stage IIA, 70\% for IIB, $62 \%$ for stage IIIA and $31 \%$ for stage IIIB. The recurrence rate was $15 \%$ (distant) and $3 \%$ (local).

\section{CONCLUSIONS}

Robotic approach for lobectomy is one of the newest evolutions in MIS for NSCLC; however, long-term data on its oncologic efficacy are still limited. For this purpose, in this review, we have analysed ten studies, both monocentric and multicentric, to examine oncologic outcomes of patients who underwent robotic lobectomy.

Concerning short-term results, the robotic surgery has shown several promising results such as conversion rates to thoracotomy, transfusions rate, length of stay and readmission rates compared with VATS. A propensity-matched analysis conducted by Oh et al. ${ }^{[5]}$ comparing open lobectomy and robotic lobectomy showed a lower postoperative complication rate, lower mortality rate and shorter hospital stay in the robotic cohort.

The conversion rate exposed in the present review ranges between $0 \%$ and $9.8 \%$, comparable to that reported in the literature and lower than that of VATS ${ }^{[16-18]}$. Only one study reported a higher conversion 
Table 3. Stage specific overall survival according to the eighth edition of TNM

\begin{tabular}{lcc}
\hline Stage & Two-year survival & Five-year survival \\
\hline IA1 & $97 \%$ & $92 \%$ \\
IA2 & $94 \%$ & $83 \%$ \\
IA3 & $90 \%$ & $77 \%$ \\
IB & $87 \%$ & $68 \%$ \\
IIA & $79 \%$ & $60 \%$ \\
IIB & $72 \%$ & $53 \%$ \\
IIIA & $55 \%$ & $36 \%$ \\
IIIB & $44 \%$ & $26 \%$ \\
IIIC & $24 \%$ & $13 \%$ \\
IVA & $23 \%$ & $10 \%$ \\
IVB & $10 \%$ & $0 \%$ \\
\hline
\end{tabular}

rate in patients who underwent surgery after induction therapies (15\% vs. 9.9\%); however, this study showed the feasibility and safety of robotic approach even after neoadjuvant chemo-radiotherapy ${ }^{[14]}$.

The 30-day mortality rate of the entire population examined in this review is $0.25 \%$ (range $0 \%-4.9 \%$ ). According to a recent meta-analysis conducted by O'Sullivan et al ${ }^{[19]}$, the mortality rate is lower for patients who underwent robotic surgery compared to VATS or Open approaches with an overall protective effect of robotic over thoracotomy [OR: $0.53,95 \% \mathrm{CI}: 0.33-0.85(P=0.008)$ ] and over VATS [OR: $0.61,95 \% \mathrm{CI}: 0.45-$ $0.83(P<0.001)]$. Notwithstanding these results should be thoughtfully considered, given that a possible selection bias in robotic cohort may have occurred, data on short-term outcomes of robotic surgery are very interesting.

Analysing the long-term results, the overall and stage-specific survival of robotic lobectomy are consistent with data reported by Goldstraw et al. ${ }^{[20]}$, which were mainly obtained by open surgery [Table 3].

According to the largest multicentre series of robotic lobectomy analyses by Cerfolio et al ${ }^{[15]}$, which also included many other examined cohorts, the OS of patients who had completely resected NSCLC via robotic lobectomy is favourable compared to open surgery. One possible explanation proposed by the authors is a reduction of immunocompromised state after MIS surgery.

Moreover, the authors stated that DFS of robotic cohort is promising, especially in case of N2 disease. This is probably due to the easier and more precise dissection of lymph node during robotic surgery, which also leads to superior upstaging compared to VATS, improved staging and greater chance to undergo adjuvant chemotherapy $^{[21]}$.

Our review reports good short- and long-term outcomes after robotic lobectomy for NSCLC, which combines the benefits of MIS with the accuracy of open surgery in stage-assessment, showing an overall and stage-specific OS comparable with that reported by IASLC database.

\section{DECLARATIONS}

\section{Acknowledgments}

The Authors thank Teresa Hung Key for linguistic accuracy checking.

\section{Authors' contributions}

Conception and design, collection and assembly of data, data analysis and interpretation: Ricciardi S

Administrative support: Melfi FMA, Davini F

Provision of study materials or patients: Davini F, Romano G, Zirafa CC 
Manuscript writing and final approval of manuscript: Ricciardi S, Davini F, Zirafa CC, Romano G, Melfi FMA

\section{Availability of data and materials}

Not applicable.

\section{Financial support and sponsorship}

None.

\section{Conflicts of interest}

Prof. Melfi is an official proctor for Intuitive Surgical. Drs. Davini, Ricciardi, Zirafa and Romano have no conflict of interest or financial ties to disclose.

\section{Ethical approval and consent to participate}

Not applicable.

\section{Consent for publication}

Not applicable.

\section{Copyright}

(C) The Author(s) 2020.

\section{REFERENCES}

1. NCCN guidelines, Version 5.2019, NSCLC. Available from https://www.nccn.org/professionals/physician_gls/default.aspx [Last accessed on 31 Dec 2019]

2. Paul S, Altorki NK, Sheng S, Lee PC, Harpole DH, et al. Thoracoscopic lobectomy is associated with lower morbidity than open lobectomy: a propensity-matched analysis from the STS database. J Thorac Cardiovasc Surg 2010;13:366-78.

3. Yang CJ, Kumar A, Klapper JA, Hartwig MG, Tong BC, et al. A national analysis of long-term survival following thoracoscopic versus open lobectomy for stage I non-small-cell lung cancer. Ann Surg 2019;269:163-71.

4. Berry MF, D'Amico TA, Onaitis MW, Kelsey CR. Thoracoscopic approach to lobectomy for lung cancer does not compromise oncologic efficacy. Ann Thorac Surg 2014;98:197-202.

5. Oh DS, Reddy RM, Gorrepati ML, Mehendale S, Reed MF. Robotic-assisted, video-assisted thoracoscopic and open lobectomy: propensity matched analysis of recent premier data. Ann Thorac Surg 2017;104:1733-40.

6. Toosi K, Velez-Cubian FO, Glover J, Ng EP, Moodie CC, et al. Upstaging and survival after robotic-assisted thoracoscopic lobectomy for non-small cell lung cancer. Surgery 2016;160:1211-8.

7. Yang HX, Woo KM, Sima CS, Bains MS, Adusumilli PS, et al. Long-term survival based on the surgical approach to lobectomy for clinical stage I nonsmall cell lung cancer: comparison of robotic, video-assisted thoracic surgery, and thoracotomy lobectomy. Ann Surg 2017;265:431-7.

8. Lee BE, Shapiro M, Rutledge J, Korst RJ. Nodal upstaging in robotic and video assisted thoracic surgery lobectomy for clinical n0 lung cancer. Ann Thorac Surg 2015;100:229-33.

9. Gharagozloo F, Margolis M, Tempesta B. Robot-assisted thoracoscopic lobectomy for early-stage lung cancer. Ann Thorac Surg 2008;85:1880-5.

10. Cheufou DH, Mardanzai K, Ploenes T, Theegarten D, Stamatis G, et al. Effectiveness of robotic lobectomy-outcome and learning curve in a high volume center. Thorac Cardiovasc Surg 2019;67:573-7.

11. Casiraghi M, Galetta D, Borri A, Tessitore A, Romano R, et al. Ten years' experience in robotic-assisted thoracic surgery for early stage lung cancer. Thorac Cardiovasc Surg 2019;67:564-72.

12. Zirafa CC, Cavaliere I, Ricciardi S, Romano G, Davini F, et al. Long-term oncologic results for robotic major lung resection in nonsmall cell lung cancer (NSCLC) patients. Surg Oncol 2019;28:223-7.

13. Park BJ, Melfi F, Mussi A, Maisonneuve P, Spaggiari L, et al. Robotic lobectomy for non-small cell lung cancer (NSCLC): long-term oncologic results. J Thorac Cardiovasc Surg 2012;143:383-9

14. Veronesi G, Park B, Cerfolio R, Dylewski M, Toker A, et al. Robotic resection of Stage III lung cancer: an international retrospective study. Eur J Cardiothorac Surg 2018;54:912-9.

15. Cerfolio R, Ghanim AF, Dylewski M, Veronesi G, Spaggiari L, et al. The long-term survival of robotic lobectomy for non-small cell lung cancer: a multi-institutional study. J Thorac Cardiovasc Surg 2018;155:778-86.

16. Takagi H, Yamamoto H, Goto SN, Matsui M, Umemoto T. Perioperative results of robotic lung lobectomy: summary of the literature. Surg Endo 2012;26:3697-9. 
17. Yang CF, Sun Z, Speicher PJ, Saud SM, Gulack BC, et al. Use and outcomes of minimally invasive lobectomy for stage I non-small cell lung cancer in the National Cancer Data Base. Ann Thorac Surg 2016;101:1037-42.

18. Liang H, Liang W, Zhao L, Chen D, Zhang J, et al. Robotic versus video-assisted lobectomy/segmentectomy for lung cancer: a metaanalysis. Ann Surg 2018;268:254-9.

19. O'Sullivan KE, Kreaden US, Hebert AE, Eaton D, Redmond KC. A systematic review and meta-analysis of robotic versus open and video-assisted thoracoscopic surgery approaches for lobectomy. Interact CardioVasc Thorac Surg 2019;28:526-34.

20. Goldstraw P, Chansky K, Crowley J, Rami-Porta R, Asamura H, et al. The IASLC lung cancer staging project: proposals for revision of the TNM stage groupings in the forthcoming (eighth) edition of the TNM classification for lung cancer. J Thorac Oncol 2016;11:39-51.

21. Wilson JL, Louie BE, Cerfolio RJ, Park BJ, Vallières E, et al. The prevalence of nodal upstaging during robotic lung resection in early stage non-small cell lung cancer. Ann Thorac Surg 2014;97:1901-7. 